\title{
Natural Sarcocystis gigantea infection in sheep from Southern Brazil
}

\author{
Infecção natural por Sarcocystis gigantea em ovinos no Rio Grande do Sul
}

\author{
Pedro Araujo Damboriarena ${ }^{\mathrm{I}}$ Caroline Silva Silveira ${ }^{\mathrm{I}}$ \\ Raissa Moreira Morais ${ }^{I}$ Bruno Leite Anjos ${ }^{I^{*}}$
}

- NOTE -

\section{ABSTRACT}

Protozoal diseases caused by species of Sarcocystis can cause serious damage in sheep flocks, inducing decreased growth conversion rates and partial or complete loss of carcasses at the slaughterhouse. This article describes an outbreak of Sarcocystis gigantea infection in sheep slaughtered in a farm in Rio Grande do Sul State, Brazil. Between July and September 2013, three sheep showed multiple nodules in the esophagus that were microscopically characterized as encapsulated cysts filled with elongated, basophilic, nucleated structures morphologically consistent with $\boldsymbol{S}$. gigantea bradyzoites. Diagnosis was made based on the epidemiological, macroscopic, and microscopic findings. This is the first report of this infection in sheep in Rio Grande do Sul and should be recognized by veterinarians, especially during meat inspection.

Key words: sarcocystosis in sheep, apicomplexa, pathology.

\section{RESUMO}

Doenças causadas por protozoários do gênero Sarcocystis podem causar sérios prejuizos em rebanhos de ovinos, por induzirem retardo no crescimento e condenação parcial ou total das carcaças em abatedouro. O presente trabalho descreve a infecção natural por Sarcocystis gigantea em ovinos abatidos em uma propriedade rural no Rio grande do Sul. Entre julho e setembro de 2013, três ovinos apresentaram múltiplos nódulos no esôfago, os quais, microscopicamente, corresponderam a cistos circundados por cápsula rugosa, repletos de estruturas alongadas, basofilicas e nucleadas, morfologicamente compativeis com bradizoitos de $\boldsymbol{S}$. gigantea. Os dados epidemiológicos unidos aos achados macroscópicos e microscópicos permitiram o diagnóstico conclusivo. Esse foi o primeiro relato dessa infecção no Rio Grande Sul e deve ser reconhecida por veterinários de campo e especialmente no momento da inspeção das carcaças no abatedouro.

Palavras-chave: sarcocistose em ovino, apicomplexa, patologia.
Lesions caused by protozoal diseases can cause economic losses due to decreased production rates or death of the most severely infected animals (ADRIANA et al., 2008). Sarcocystosis caused by species of Sarcocystis is responsible for the formation of cysts in different organs, which are often observed in the skeletal and cardiac muscle, and has a high prevalence in sheep, resulting in serious injury in different organ systems, abortion, and death (MARTÍNEZ-NAVALÓN et al., 2012).

Sarcocystis gigantea is a parasite with worldwide distribution responsible for development of macroscopic cysts in sheep (BEYAZIT et al., 2007; MARTÍNEZ-NAVALÓN et al., 2012; DEHAGHI et al., 2013). It belongs to the phylum Apicomplexa, family Sarcocystidae, and genus Sarcocystis. It is also referred to as Sarcocystis ovifelis, because cats are the definitive hosts, while sheep are the intermediate hosts. S. gigantea is responsible for forming cysts mainly in the tongue and esophageal muscles, and their presence in the muscles and viscera of carcasses in the slaughterhouse causes economic losses due to the partial or total loss of carcasses (MARTINEZNAVALON et al., 2012). This study reports the occurrence of natural infection by Sarcocystis gigantea in sheep in Rio Grande do Sul.

Between July and September 2013, visits were made to a farm in Santana do Livramento that had 300 adult Corriedale sheep and 250 Corriedale lambs destined for slaughter. According to the owner,

\footnotetext{
'Laboratório de Patologia Veterinária, Hospital Veterinário Universitário, Universidade Federal do Pampa (UNIPAMPA), Campus Uruguaiana, BR 472, Km 592, 97500-970, Uruguaiana, RS, Brasil. E-mail: anjosbl@gmail.com. "Corresponding author. 
the flock was raised in consortium with cattle and horses and was fed with native pasture with mineral supplementation. During evaluation, 12 sheep (4-6 years old) were slaughtered in the farm. Three sheep showed white nodules in the esophageal muscles that were collected in $10 \%$ formalin and sent for histopathological evaluation. Cats and dogs had free access to pastures and livestock; they were observed on site during the slaughter and ingested uncooked meat and viscera from slaughtered sheep.

Macroscopically, multiple esophageal nodules were observed during slaughter. They were characterized by white, round or oval cysts with $1.5 \times 1.0 \times 1.0 \mathrm{~cm}$, distributed randomly throughout esophageal muscles (Figure 1A). Cysts had a white capsule and internal gelatinous translucent material. After previous evaluation, fragments were embedded in paraffin, sectioned in $3 \mu \mathrm{m}$ for histopathology slides, and stained with hematoxylin and eosin (Figure 1B). Microscopically, the cysts showed irregularly shaped, eosinophilic wall with placentiformes protrusions, and adjacent connective tissue capsule. Random, eosinophilic projections supported the basophilic, $4 \mu \mathrm{m}$ elongated structures, which had evident nucleus and granular cytoplasm that was morphologically consistent with bradyzoites of Sarcocystis gigantea (Figure 1C and 1D).

Diagnosis of sarcocystosis by Sarcocystis gigantea was confirmed by epidemiologic, macroscopic, and microscopic findings (DUBEY

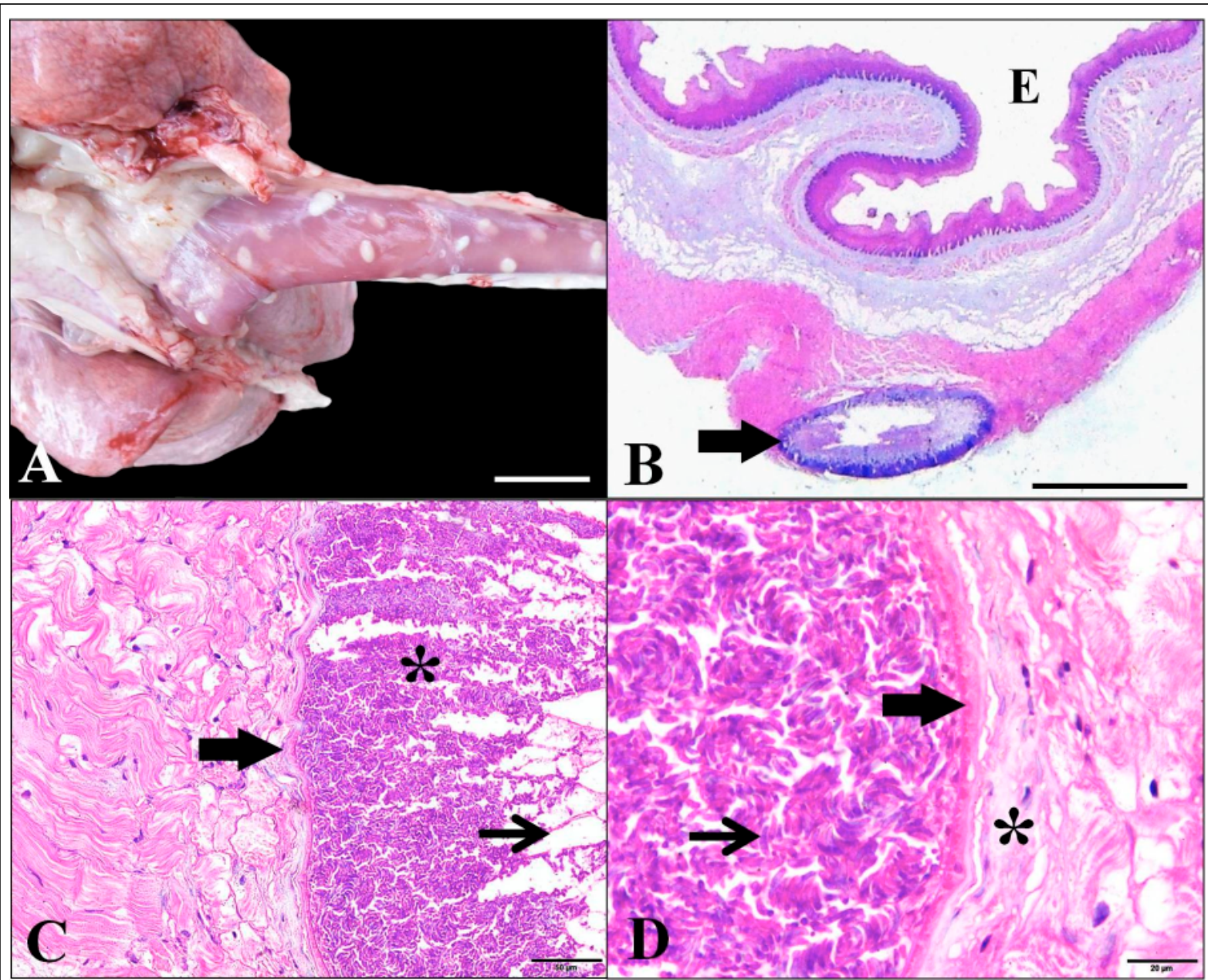

Figure 1 - Sheep esophagus: (A) Multiple oval and whitish cysts in the esophageal muscles. Bar $=2 \mathrm{~cm}$. (B) Cross section of esophagus with cysts of Sarcocystis gigantea in the muscular layer (thick arrow). Esophageal lumen (E). Hematoxylin and eosin. Bar $=1 \mathrm{~cm} .(\mathrm{C})$ Striated skeletal muscle with cyst $\boldsymbol{S}$. gigantea. Note that the wall of the cyst is irregular and surrounded by capsule (thick arrow) and inside are observed numerous basophilic structures (*) supported by thin septa from the capsule (thin arrow). Hematoxylin and eosin. Bar $=50 \mu \mathrm{m}$. (D) Cyst of $\boldsymbol{S}$. gigantea with eosinophilic internal capsule with placentiformes ripples (thick arrow). It is observed thin connective tissue capsule surrounding the cyst $\left(^{*}\right)$ and several elongated basophilic bradyzoites (thin arrow). Hematoxylin and eosin. Bar $=20 \mu \mathrm{m}$. 
et al., 1988; BEYAZIT et al., 2007; AL-HYALI et al., 2011). The main risk factors for infection are the contact of the definitive host with the agent and the supply of raw meat from sheep to cats, which contributes significantly to the propagation of sarcocystosis by $\boldsymbol{S}$. gigantea, as well as other species of Sarcocystis sp. transmitted by canids (ADRIANA et al., 2008).

Sheep are infected with $\boldsymbol{S}$. gigantea when they ingest oocysts or sporocysts that are eliminated with feces of cats (MCKENNA \& CHARLESTON, 1988). Sporozoites originated meronts which, upon maturation, release merozoites that penetrate endothelial cells to originate secondary merozoites. These merozoites are released and can penetrate in muscle cells and will develop bradyzoites and cysts (MCKENNA, 1984). These cysts are similar to described in this note.

Most species of Sarcocystis that infect domestic animals are species-specific for the intermediate host (DUBEY et al., 1988). Sheep are intermediate hosts for four species of Sarcocystis: $S$. gigantea and S.medusiformis, which are transmitted by felids and are less pathogenic; and $\boldsymbol{S}$. tenella and $S$. arieticanis, which are transmitted by canids and are more pathogenic, causing neurological disease and abortion (ADRIANA et al., 2008; DEHAGHI et al., 2013). The differentiation between $\boldsymbol{S}$. gigantea and other species Sarcocystis was made based on the morphology of cysts (DUBEY et al., 1988; BEYAZIT et al., 2007). Cyst size varies according to the degree of maturation, and microscopically differentiation of each species and can be defined through the aspect of the wall. Shape and thickness of the wall can allow the definitive diagnosis (MARTINEZ-NAVALON et al., 2012; DEHAGHI et al., 2013).

Similar to the cases described in the current article, $\boldsymbol{S}$. gigantea macrocyst showed irregular thick wall, with placentiformes protrusions and a secondary wall of connective tissue (MUNDAY \& OBENDORF, 1984). S. medusiformis also has thick wall, but induces the formation of smaller cysts. $\boldsymbol{S}$. medusiformis geographical distribution is restricted to Australia, New Zealand, and Iran (FARHANG-PAJUH et al., 2014). Both $\boldsymbol{S}$. gigantea and $\boldsymbol{S}$. medusiformis are reported as non-pathogenic species, but can cause losses in the slaughterhouse and myositis when rupture of cysts occurs (AL-HYALI et al., 2011). This inflammatory lesion was not observed in the evaluated sheep.

Differently the previously mentioned species, $\boldsymbol{S}$. tenella and $\boldsymbol{S}$. arieticanis are pathogenic protozoa that cause microscopic cysts. S. tenella has a thick wall and presence of villi without $2-4 \mu \mathrm{m}$ (BEYAZIT et al., 2007) and may cause nervous clinical signs, as well as abortion, decreased milk production, anemia, decreased weight gain and, in severe cases, death (SILVA et al., 2009). $S$. arieticanis showed cyst between $53-163 \mu \mathrm{m}$ diameter, and a thin wall with filiform projections with $6-12 \mu \mathrm{m}$ (DUBEY et al., 1988).

Several studies demonstrate a high prevalence of infections with Sarcocystis sp. in sheep (BEYAZIT et al., 2007; ADRIANA et al., 2008; MARTÍNEZ-NAVALON et al., 2012; BAHARI et al., 2014.). In Brazil, studies of non-pathogenic species of Sarcocystis are uncommon and the occurrence of S. gigantea in sheep is underestimated in Rio Grande do Sul and Uruguay due to failure in the diagnosis. High prevalence of sarcocystosis by $\boldsymbol{S}$. gigantea in sheep is reported in Iraq and mineralized cysts are observed in some cases (AL-HYALI et al., 2011). The high number of cases is a determining factor for reinfection of the definitive host and perpetuation of the life cycle of the parasite (DEHAGHI et al., 2013).

According to the farmer, young sheep were slaughtered on the property and cystic lesions were not observed. This may have occurred by the short exposure time of sheep to oocysts in the feces of the definitive host (cat) or the prolonged development of macroscopic cyst (MCKENNA, 1984). However, it has been described cysts in animals less than one year old, suggesting cyst growth less than one year (BEYAZIT et al., 2007). After the diagnosis, the owner was advised to not give carcasses remains and uncooked guts to cats in order to minimize contact between cats and sheep.

Although the lesions caused by $\boldsymbol{S}$. gigantea are mild in most cases, in marked infections, the parasite can cause considerable losses in slaughterhouse (NAVALON-MARTINEZ et al., 2012). This report demonstrated the infection by S. gigantea occurs in sheep from Rio Grande do Sul. Lesions must be recognized by veterinarians, especially in the slaughterhouse. In addition, the diagnosis may indicate the infection by pathogenic protozoa of the phylum Apicomplexa in sheep, due to the similarities in protozoa life cycle.

\section{REFERENCES}

ADRIANA, T. et al. Epidemiology and etiology in sheep sarcocystosis. Bulletin of University of Agricultural Sciences and Veterinary Medicine, v.65, n.2, p.49-54, 2008. Available from: <http://journals.usamvcluj.ro/index.php/veterinary/article/ view/1522>. Accessed: Jan. 11, 2014. 
AL-HYALI, N.S. et al. Fate of macrosarcocyst of Sarcocystis gigantea in sheep. Iraq Journal of Veterinary Sciences, v.25, n.2, p.87-91, 2011. Available from: <http://www.vetmedmosul. org/ijvs/media/11-2-9e.pdf $>$. Accessed: Jan. 11, 2014.

BAHARI, P. et al. Molecular identification of macroscopic and microscopic cysts of Sarcocystis in sheep in North Khorasan Province, Iran. International Journal of Molecular and Cellular Medicine, v.3, n.9, p.51-56, 2014. Available from: <http://www.ncbi.nlm.nih. gov/pmc/articles/PMC3927390/>. Accessed: Jan. 11, 2014.

BEYAZIT, A. et al. The prevalence of ovine Sarcocystis species in Izmir province. Ankara Üniversitesi Veteriner Fakültesi Dergisi, v.54, n.2, p.111-116, 2007. Available from: <http:// acikarsiv.ankara.edu.tr/browse/8820/>. Accessed: Jan. 11, 2014.

DEHAGHI, M.M et al. Survey of Sarcocystis infection in slaughtered sheep in Kerman Abattoir, Kerman, Iran. Comparative Clinical Pathology, v.22, n.3, p.343-346, 2013. Available from: $<$ http://link.springer.com/article/10.1007/s00580-012-1414-9>. Accessed: Jan. 11, 2014. doi: 10.1007/s00580-012-1414-9.

DUBEY, J.P. et al. Sarcocystis arieticanis and other Sarcocystis species in sheep in the United States. Journal of Parasitology, v.74, n.6, p.1033-1038, 1988. Available from: <http://www.ncbi. nlm.nih.gov/pubmed/3142990>. Accessed: Jan. 11, 2014.

FARHANG-PAJUH, F. et al. Molecular determination of abundance of infection with Sarcocystis species in slaughtered sheep of Urmia, Iran. Veterinary Research Forum, v.5, n.3, p.181-186, 2014. Available from: <http://vrf.iranjournals.ir/ article_6616_940.html>. Accessed: Jan. 11, 2014.
MCKENNA, P.B. Sarcocystis giantea: studies on sporocyt production, excystation and viability. 1984. 228f. Tese (Doutorado em Medicina Veterinária) - Massey University. Available from: <http://mro.massey.ac.nz/handle/10179/3161>. Accessed: Jan. 11, 2014.

MCKENNA, P.B.; CHARLESTON, W.A.G. Recovery of Sarcocystis gigantea sporocystis from cat faeces. Veterinary Parasitology, v.26, n.3-4, p.215-227, 1988. Available from: $<$ http://www.ncbi.nlm.nih.gov/pubmed/3126598>. Accessed: Jan. 11, 2014. doi: 10.1016/0304-4017(88)90090-8.

MARTÍNEZ-NAVALÓN, B. et al. Short communication. Sarcocystis infection: a major cause of carcass condemnation in adult sheep in Spain. Spanish Journal of Agricultural Research, v.10, n.2, p.388-392, 2012. Available from: $<$ http://revistas.inia.es/ index.php/sjar/article/view/2270>. Accessed: Jan. 11, 2014. doi: 10.5424/sjar/2012102-523-11.

MUNDAY, B.L.; OBENDORF, D.L. Morphology of Sarcocystis gigantea in experimentaly-infected sheep. Veterinary Parasitology, v.16, n.3-4, p.193-199, 1984. Available from: <http://www.sciencedirect.com/science/ article/pii/0304401784900360>. Accessed: Jan. 11, 2014. doi: 10.1016/0304-4017(84)90036-0.

SILVA, R.C. et al. First identification of Sarcocystis tenella (Railliet, 1886) Moulé, 1886 (Protozoa: Apicomplexa) by PCR in naturally infected sheep from Brazil. Veterinary Parasitology, v.165, n.3-4, p.332-336, 2009. Available from: <http://www.ncbi. nlm.nih.gov/pubmed/19647370>. Accessed: Jan. 11, 2014. doi: 10.1016/j.vetpar.2009.07.016. 